\title{
BRENERIO NAVIKO RADIOLOGINĖS DIAGNOSTIKOS YPATUMAI. KLINIKINIS ATVEJIS
}

\author{
Rasita Pavilioné ${ }^{1}$, Laura Dobrovaité2 ${ }^{2}$ Orinta Klimait $\dot{e}^{2}$ \\ ${ }^{1}$ Respublikiné Klaipédos ligonine, \\ ${ }^{2}$ Lietuvos sveikatos mokslu universiteto Medicinos akademijos Medicinos fakultetas
}

Raktažodžiai: Brenerio navikas, epiteliniai kiaušidžių navikai, magnetinio rezonanso tyrimas.

\begin{abstract}
Santrauka
Brenerio navikas priskiriamas epitelinių kiaušidžių navikų grupei. Dažniausiai tai gerybinis navikas, ịprastai randamas atsitiktinai, itin retais atvejais gali būti randamos ir piktybinès jo formos. Brenerio naviko dažnai nepavyksta diferencijuoti nuo kitų kiaušidžių neoplastinių darinių, remiantis vien klinikiniais ir radiologiniais tyrimais - diagnozei patikslinti reikalingas histologinis tyrimas. Pagrindinis šio naviko gydymas yra chirurginis, todèl labai svarbi priešoperacinè diagnozè, kuri lemia operacijos radikalumą. Šiuo klinikiniu atveju Brenerio navikas rastas magnetinio rezonanso metu ir diagnozé patikslinta histologiniu tyrimu.
\end{abstract}

\section{Ivadas}

Brenerio navikas yra reta adenofibroma, sudaranti vos 2 proc. visų kiaušidžių navikų [1]. Šis navikas dažniausiai gerybinis, randamas atsitiktinai ir būdingas pomenopauzinio amžiaus moterims [1]. Brenerio navikas gali būti kartu su kita moters lytinių takų patologija bei tumorais [2]. Retais atvejais šis navikas imituoja kiaušidžių vèži, todèl labai svarbi šių dviejų patologijų diferenciacija [3]. Šio tumoro diagnostika yra sudètinga, kadangi jis neturi specifinių radiologinių požymių [2]. Šiame straipsnyje apžvelgiamas gerybinio Brenerio naviko klinikinis atvejis, kurio diagnostikai naudotas magnetinio rezonanso tyrimas (MRT) ir pateikiami radiologiniai vaizdai.

Tyrimo tikslas - pristatyti Brenerio naviko klinikini atveji, aprašant retą patologiją, kurios tiksli diagnozė buvo nustatyta tik atlikus išsamesnius radiologinius ir histologini tyrimus.

\section{Klinikinis atvejis}

60 metų pacientẻ kreipèsi ị Klaipèdos respublikinès ligo- ninès prièmimo skyrių dèl skausmų pilvo apačioje. Atliktas ginekologinis ištyrimas. Jo metu rasta saikinga makšties atrofija, epitelizuotas gimdos kaklelis, gimda paslanki, anteversijos padètyje, abipus čiuopiami saikiai padidèję, neskausmingi ir paslankūs gimdos priedai. Atliktas transvaginalinis ultragarso tyrimas (TVUG): gimda 38,6x23,6 mm, endometriumas seklus, abipus kiaušidèse diferencijuojami nehomogeniški, hipoechogeniški intarpai: kairèje $\sim 27,9 \times 24,7 \mathrm{~mm}$ ir dešinèje $\sim 18,1 \times 28,2 \mathrm{~mm}$, laisvo skysčio nematyti. Pacientei jau 11 metų menopauzè. Véžio žymens CA 125 koncentracija normali. Atlikus tyrimus nuspręsta, kad ūmios ginekologinès ir chirurginès patologijos nèra, todèl pacientei planine tvarka skirtas mažojo dubens magnetinio rezonanso tyrimas (MRT), kurio rezultatai parodyti 1,2,3 ir 4 paveiksluose.

Radiologo išvada: MRT abipus kiaušidèse mišrios struktūros dariniai su ịtartinais radiologiniais piktybiškumo požymiais. Rekomenduojama histologinè verifikacija.

Paciente stacionarizuota ị ginekologijos skyrių, kuriame jai atlikta adnexectomia bilateralis per laparoscopiam.

Pooperacinès medžiagos histologinio tyrimo rezultatai: abipus kiaušidèse matomi ịvairaus stambumo epiteliniai lizdai su kalcifikatais, keli cistiški, apsupti fibrotizuotos stromos, suformuoti iš pereinamojo epitelio, teigiamo CK7, p63 imunožymenims, neigiamo CK20, Ki67 proliferacinis aktyvumas žemas, apie 2 procentai. Kiaušintakių sienelès fibrotizuotos. Išvada: gerybinis kiaušidžių Brenerio navikas.

\section{Diskusija}

Brenerio navikas - tai iš kiaušidžių epitelio kilęs navikas, pirmą kartą aprašytas 1907 metais gydytojo Fritz Brenner [4]. Neoplaziniai dariniai kiaušidèse yra dažna patologija, kuri sudaro apie 30 proc. visų navikinių darinių moters lytiniuose takuose [5]. Brenerio navikas yra retas ir sudaro tik 2 proc. visų kiaušidžių navikų [1]. Pasaulio sveikatos organizacija ši naviką klasifikuoja ị tris kategorijas: gerybiniai, ribinio piktybiškumo ir piktybiniai [3].

Klinika. Brenerio navikas gali pasireikšti bet kurio 
amžiaus moterims, tačiau dažniausiai randamas moterims apie 50-70 metų amžiaus, tačiau ribinio piktybiškumo ar piktybinès formos navikai labiau būdingi 60-80 metu pacientèms $[4,6]$. Šis navikas dažniausiai yra besimptomis ir randamas atsitiktinai, atliekant ginekologinị ištyrimą ar echoskopuojant, tačiau kartais gali pasireikšti tokiais simptomais kaip pilvo skausmas, vaginalinis kraujavimas, šlapimo susilaikymas, ascitas ar pseudo-Meigs sindromas [4]. Esant ribinio
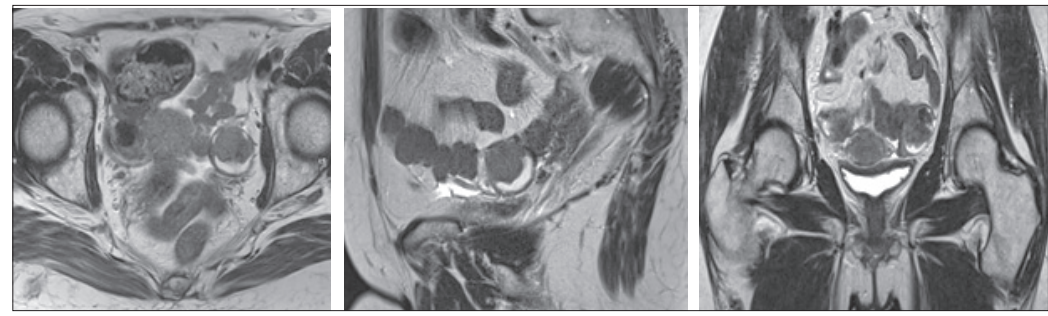

1 pav. T2 tse_bl aksialinis, sagitalinis ir koronarinis vaizdai. Abipus kiaušidèse matomi iki 2,6×2,5×2,2 cm dydžio, aiškių ribų, mišrios struktūros dariniai, turintys solidinị ir cistinị komponentą piktybiškumo navikui, gali pasireikšti simptomai, tokie kaip pilnumo jausmas su pilvo skausmu, pomenopauzinis kraujavimas bei svorio kritimas ir anoreksija [3].

Histologija. Brenerio navikas yra reta adenofibroma [1]. Mikroskopiškai Brenerio navikas susidaro iš gerai ribotu epitelio ląstelių lizdelių, apsuptų tankia fibrozine stroma. Epitelio ląstelès turi būdingą kavos pupelès formos branduolị su išilginiais grioveliais ir ji supančią blyškią citoplazmą [4,5]. Šio naviko epitelio ląstelès yra panašios ị urotelio ląsteles, todèl PSO šį naviką priskiria pereinamojo epitelio navikų tipui [5]. Gali būti matomi ryškūs kalcifikatai [4]. İprastai gerybinis Brenerio navikas lokalizuojasi vienoje pusejje, o piktybinis - abipus [2]. Gerybiniai navikai gali būti 5-6 cm skersmens, išskirtiniais atvejais gali siekti $10 \mathrm{~cm}$ [7]. Ribinio piktybiškumo ir piktybinių Brenerio navikų diametras gali siekti net iki 30 centimetru [8].

Ultragarsinè diagnostika. Diagnozuoti Brenerio naviką naudojantis vien radiologiniais vaizdais yra sudetinga, nes šio naviko vaizdas yra nespecifinis [2]. Brenerio naviko sonografiniai vaizdai gali būti skirtingi, o kad jis yra itin retas, labai sunkina šio naviko ultragarsinę diagnostiką [4]. Nèra vieno išskirtinio požymio, leidžančio diagnozuoti Brenerio naviką, tačiau tam tikrų požymių kompleksas gali leisti ji itarti [4]. Kalcifikacijos su šešèliu, menkai vaskuliarizuota solidinè struktūra, matoma kaip hipoechogeninis signalas su šešèliu, dažniausiai kairejje pusejje lokalizuota struktūra, galètų leisti ịtarti gerybinị Brenerio naviką [4,7].

Kompiuterinès tomografijos vaizduose matomas kaip nedidelis, solidinis tumoras, gali būti tiek homogeniškos, tiek nehomogeniškos struktūros $[5,9]$. Dažnai gali būti matomi ir dauginiai kalcifikacijos židinukai solidiniame naviko plote [5]. Brenerio navikas gali tureti ir kitų tipų navikų komponentų, dažniausiai kiaušidžių cistadenomos $[9,10]$. Tokiais atvejais gali būti matomas kaip solidinis - cistinis tumoras arba cistinis tumoras su dauginiais kalcifikacijos židinèliais [5,9].

Magnetinio rezonanso tyrimo vaizduose Brenerio naviko gausūs fibrotiniai komponentai ir kalcifikacijos matomi kaip ryškiai hipointensiniai T2 režime $[8,10]$. Be to,

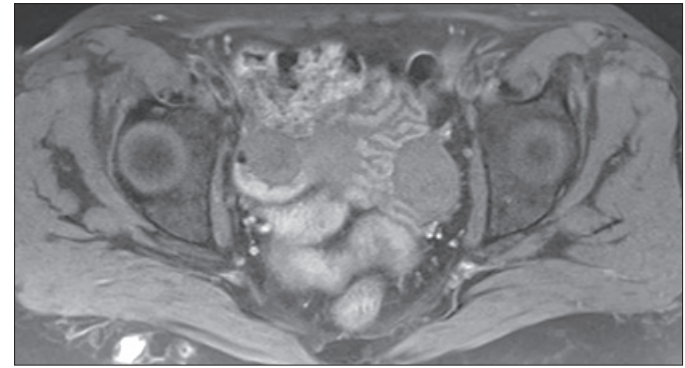

2 pav. T1_vibe_fs, aksialinis vaizdas. Kiaušidèse aukšto intensyvumo izointensinis signalas (lyginant su raumenimis)

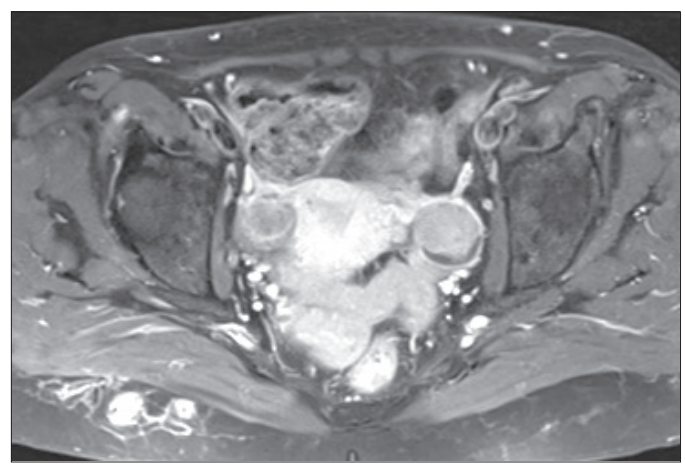

3 pav. T1_vibe_fs + C, aksialinis vaizdas. Abipus kiaušidžių darinių solidinis komponentas saikiai kaupia kontrastinę medžiagą

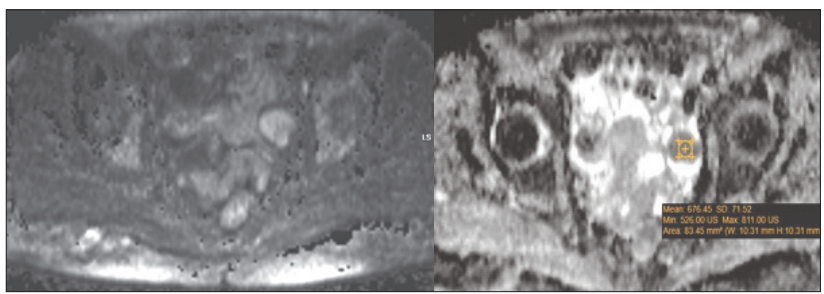

4 pav. DWI $(b=800)$ ir ADC sekos. DWI sekoje (aukšta b vertè) kairèje darinys išlieka aukšto signalo intensyvumo, restrikcijos požymiai $\left(A D C=0,6 \times 10-3 \mathrm{~mm}^{2} / \mathrm{s}\right)$. Dubens ertmėje padidejusių, specifiškai pakitusių limfmazgių nematyti 
šis navikas paprastai yra žemesnio intensyvumo signalo T2 režime nei kiti solidiniai tumorai [8]. Apie 20 proc. Brenerio navikų susiję su kitomis gleivinès cistadenomomis ar kitomis epitelinèmis neoplazmomis [10]. Tokiais atvejais cistinis komponentas reprezentuoja gleivinès cistinį tumorą, o solidinis komponentas - Brenerio naviką [11]. Vaizdas tokiais atvejais taip pat yra labai žemo intensyvumo signalo T2 režime [8,10,11].

Gydymas. Brenerio navikų pagrindinis gydymas yra chirurginis [2]. İtarus naviko piktybinị potencialą, pavyzdžiui, ribinio piktybiškumo Brenerio naviko atveju, rekomenduojama atlikti chirurginį naviko stadijavimą [3]. Ne visada reikalingas visas chirurginis naviko stadijavimas, kadangi piktybiniai Brenerio navikai dažniausiai randami lokalizuoti, pirmos stadijos, o metastazès limfmazgiuose randamos tik 5,1 proc. pacientų [2].

\section{Išvados}

1. Brenerio navikas dažniausiai yra asimptomis ir randamas atsitiktinai, tiriant dubenị UG arba atliekant chirurgines dubens intervencijas.

2. Svarbu atskirti Brenerio naviką imituojantị piktybinị epitelinį kiaušidžių vėžị, lemiantị skirtingas prognozes ir gydymo ypatumus. Tinkama gerybinio Brenerio naviko diagnoze prieš chirurgini gydymą leidžia sumažinti operacijos radikalumą.

3. Ivairių sričių specialistams - akušeriams ginekologams, vidaus ligu gydytojams, gydytojams radiologams ir kitiems, ịtarusiems kiaušidžiu vėži, ị diferencinę diagnozę verta ịtraukti ir Brenerio naviką.

\section{Literatūra}

1. Dougherty D, Onyemkpa C, Engel M, Oyasiji T. A case report of an incidental Brenner tumor found after resection of a large ovarian mucinous neoplasm. Int J Surg Case Rep 2018;49:40-3. https://doi.org/10.1016/j.ijscr.2018.05.007

2. Turgay B, Koyuncu K, Taşkın S, Ortaç UF. Ovaryan Brenner tümörlerinin özellikleri: Üçüncü basamak merkez tecrübesi. Turk Jinekoloji ve Obstet Dern Derg 2017;14(2):133-7. https://doi.org/10.4274/tjod.98216

3. Zheng R, Heller DS. Borderline Brenner tumor: a review of the literature. Vol. 143, Archives of Pathology and Laboratory Medicine. College of American Pathologists 2019;143:1278-80. https://doi.org/10.5858/arpa.2018-0285-RS

4. Weinberger V, Minář L, Felsinger M, Ovesná $\mathrm{P}$, Bednaříková $\mathrm{M}$, Číhalová M, et al. Brenner tumor of the ovary - ultrasound features and clinical management of a rare ovarian tumor mimicking ovarian cancer. Ginekol Pol 2018;89(7):357-63. https://doi.org/10.5603/GP.a2018.0061
5. Gaur JH, Hassan MJ, Elahi AA, Khetrapal S, Khan S, Jetley S. Synchronous benign Brenner's tumor of ovary with leiomyoma and endometrial adenocarcinoma in a postmenopausal female. $\mathrm{J}$ Cancer Res Ther 2019;15(6):1418-20. https://doi.org/10.4103/ jcrt.JCRT_109_18

6. Zhao Y, Mao X, Yao L, Shen J. Computed tomography imaging features of benign ovarian brenner tumors. Oncol Lett 2018;16(1):1141-6. https://doi.org/10.3892/ol.2018.8766

7. Wilson MP, Katlariwala P, Hwang J, Low G. Radiographic features of a benign mixed brenner tumor and mucinous cystadenoma: a rarely identified ovarian neoplasm on imaging. J Clin Imaging Sci 2020;10(1).

https://doi.org/10.25259/JCIS_1_2020

8. Taylor EC, Irshaid L, Mathur M. Multimodality imaging approach to ovarian neoplasms with pathologic correlation. Radiographics 2021;41(1):289-315. https://doi.org/10.1148/rg.2021200086

9. Wang X, Dai J, Zhu Z, Zhao Y, Zhou C. CT features of ovarian Brenner tumor and a report of 9 cases. Zhonghua Zhong Liu Za Zhi 2010;32(5):359-62.

10. Khashper A, Addley HC, Abourokbah N, Nougaret S, Sala E, Reinhold C. T2-hypointense adnexal lesions: an imaging algorithm. Radiographics 2012;32(4):1047-64.

https://doi.org/10.1148/rg.324115180

11. Imaoka I, Wada A, Kaji Y, Hayashi T, Hayashi M, Matsuo M, et al. Developing an MR imaging strategy for diagnosis of ovarian masses. Radiographics. Radiological Society of North America 2006;26:1431-48.

https://doi.org/10.1148/rg.265045206

\section{DIAGNOSTIC PECULIARITIES OF BRENNER TUMOR: CLINICAL CASE PRESENTATION \\ R. Pavilionė, L. Dobrovaitè, O. Klimaitė}

Keywords: Brenner Tumor, epithelial ovarian tumors, magnetic resonance imaging.

Summary

A Brenner tumor is an epithelial surface tumor of the ovary. It is most commonly benign and usually found incidentally but on an extremely rare cases can be found in malignant form. It is difficult to differentiate this pathology using clinical and radiological examinations alone - histological examination is necessary for accurate diagnosis. As the surgical resection is the choice of treatment for Brenner tumors preoperative diagnosis is principal because it determines the volume of surgical treatment. In this clinical case we present a Brenner tumor clinical case where MRI was done and the histological analysis verified the diagnosis.

Correspondence to: laura.dobrov@gmail.com

Gauta 2021-02-06 